\title{
PROBLEMS OF THE CREATION AND DIRECTION OF IMPROVING THE PROFESSIONAL ETHICS OF CIVIL SERVANTS IN THE RUSSIAN FEDERATION
}

\author{
Tatiana A. Evstratova ${ }^{1}$ \\ Natalia V. Medvedeva ${ }^{2}$ \\ Elena V. Dupliy ${ }^{3}$ \\ Polina V. Palehova ${ }^{4}$
}

\begin{abstract}
A system of permanent and stable values of professional activity and value orientation determine the specifics of public administration and regulate professional behaviour of a public servant. Compliance with the norms of such behaviour is a priority indicator demonstrating the professional culture of civil servants, where the values of their activities represent a consolidating basis and act as a special cultural regulator of relations within an organization, its boundaries, as well as relations to their own actions. The main research method is an expert survey of civil servants in the
\end{abstract}

\begin{abstract}
State Duma of the Russian Federation. The purpose of this paper is to develop directions for improving the code of ethics for civil servants on the basis of identifying the problems of the creation of professional ethics for civil servants in government bodies of the Russian Federation. The study made it possible to assess the attitude of civil servants to professional ethics. Based on the results of the survey, the main negative qualities of civil servants in relation to their professional activities were identified; the key reasons for this manifestation of negative qualities and the level of
\end{abstract}

1 Candidate of Sociological Sciences, Assistant professor, Department of Management and Administration, Russian State Social University, Russian Federation, Moscow doroshenkot@yandex.ru, https://orcid.org/0000-0002-7921-4065

2 Candidate of Sociological Sciences, Assistant Professor, Department of Management and Administration, Russian State Social University, Russian Federation, Moscow nmedvedeva1984@mail.ru, https://orcid.org/0000-0001-5265-4784

3 Candidate of Historical Sciences, Assistant Professor, Department of Human Resources and Personnel Policy, Russian State Social University, Russian Federation, Moscow e-4994928284@yandex.ru, https://orcid.org/0000-0002-3611-7708

4 Doctor of historical Sciences, Professor, Deputy Director of the Center for Sustainable Development of the Institute of Finance and Sustainable Development of Ranepa, Russian Federation, Moscow ppalehova@gmail.ru, https://orcid.org/0000-0002-8905-7841 
awareness of civil servants about the content of the Code of Ethics were determined. All this necessitated the escalating of measures to modernize the Code of Ethics for civil servants. The proposed changes and additions will minimize problems in the mechanisms for the formation of professional ethics of civil servants in federal authorities.

Keywords: State civil servant, code of ethics and official conduct of a civil servant, professional ethics of civil servants.

\section{INTRODUCTION}

The success of government reforms largely depends on government officials and their willingness to do their job professionally (Hallunovi, Osmani, Bashi, 2014). The regulator of the professional behaviour of a public servant is a system of permanent and stable values of professional activity and a value orientation that defines the specifics of public administration as a professional sphere that have a significant impact on the hierarchical structure and content of the values of a public servant, which determine the motives of a person's actions and form his or her official and professional behaviour. Compliance with the norms of such behaviour is a priority indicator demonstrating the professional culture of civil servants, where the values of their activities represent a consolidating basis and act as a special cultural regulator of relations within an organization, its boundaries, as well as relations to their own actions.

Particular attention is paid to the consideration of the importance of ethics in new management practices (privatization, decentralization, debureaucratization, transfer of budgets, etc.) (Radhika, 2012). A modern civil service system should facilitate the adoption of ethical principles and values, which is a key step towards the effective professionalization of public service. Civil servants should have a clear idea of their situation and the general social significance of the activities they perform (Vasiljevic, 2016).

Ethics provides a great responsibility between citizens and the state administration and helps build confidence so that citizens can be sure that the state administration works for public ends. The development of codes of ethics, as well as the observance of fundamental principles, contributes to the creation of a professional climate in 
relations between a public servant and a citizen (Fejzullahu, Batalli, 2019). At the same time, the social attitudes of the employees themselves have a significant impact on the ethics of public administration, and its attitude to the social environment is a much stronger ethical factor in organizations of public administration than personal values (Nedelko, Potocan, 2013))

Currently, the problem of ethics and official behaviour of public servants is the subject of research by a wide range of authors, such as G.V. Atamanchuk (Atamanchuk, 2013), A.V. Obolonsky (2011), D.M. Ovsyanko (Ovsyanko, 2008), N.A. Omelchenko (Omelchenko, 2005), N.N. Shuvalova (Shuvalova, 2013), Frolov O.V. (Frolov, 2017).

A scientific discourse on the formation of professional ethics in public administration is also present in the studies of foreign scientists (BotaAvram C. (2013), Ferreira F, Castro C, Lopes C. (2019), Fejzullahu A., Batalli M. (2019 ), Hallunovi MSc., Osmani Dr.Sc, Bashi E. (2014), Radhika D. (2012)). The regional specific in the development of professional ethics demonstrated by civil servants is reflected in the works of Sumra K., Nedelko Z., Potocan V., Vasiljevic D.,
Giovanola B., Fattah M. et al. So, the subject of the study by Sumra, Kalsoom is the influence of traditional social models and cultural backgrounds on public service ethics in Pakistan (Sumra, 2019). The work by Nedelko Z., Potocan V. (Nedelko, Potocan, 2013) is devoted to the study of the interaction between employees' ethics expressed through personal values, the attitude to the natural and social environment, and public administration ethics in Slovenia. The work by Vasiljevic D. (Vasiljevic, 2016) is devoted to the analysis of the new civil service ethics system in Serbia. Practical aspects of the study of ethical principles and relations in the Italian public service system are presented in the work by Giovanola B. (Giovanola, 2011). The issues of improving the ethical monitoring and control of corruption in the US public service are investigated by Fattah M. They identify four factors that are most important for the study of the professional ethics of civil servants: principles, procedures and processes of democracy; community and institutionalization of professional ethical standards; the role of professional leadership in training and staffing; and the irrationalization of unethical behaviour (Fattah, 2011). 
The aim of our study is to develop directions for improving the code of ethics for civil servants on the basis of identifying the problems related to the creation and development of professional ethics of civil servants in the government bodies of the Russian Federation.

\section{METHODS}

The informational basis of the study is federal regulatory legal acts, statistical data and informational and analytical materials of the Central Office of the State Duma of the Federal Assembly of the Russian Federation: Federal Law dated July 27, 2004 N 79FZ "On the State Civil Service in the Russian Federation”, (2004), Decree of the President of the Russian Federation dated 01.07.2010 N 821 (as amended on 09/19/2017) “On commissions devoted to compliance with the requirements for official conduct of federal public servants and the settlement of a conflict of interest" (together with the "Regulation on commissions devoted to compliance with the requirements for official conduct of federal public servants and the settlement of a conflict of interest") (2017): Decree of the President of the Russian Federation dated 08.08.2002 N 885 (edition of 16.07.2009) "On the approval of the general official conduct principles of public servants" (2002); Methodological recommendations on the issues of reporting information on income, expenses, on property and liabilities of a property nature and filling out the corresponding certificate in 2020; Regulation on the Central Office of the State Duma of the Federal Assembly of the Russian Federation (2008); The Code of Ethics and Official Conduct of Federal State Civil Servants of the Central Office of the State Duma of the Federal Assembly of the Russian Federation dated March 14, 2011 No. 2-40 (2011), the Code of Ethics of State Servants in the Russian Federation (2010).

A survey of public civil servants in the State Duma of the Russian Federation was conducted in order to determine the features and problems on the development of professional ethics of public servants. The survey involved 74 federal government civil servants and 20 professional ethics experts. The first unit contains questions that allow us to describe the general picture of the professional ethics of civil servants in the State Duma of the Russian Federation, 
and the second contains questions that will determine the vector of necessary changes or additions that need to be made to the Code of Ethics used in the State Duma of the Federal Assembly of the Russian Federation. Dates of the survey were February 4, 2020 to February 27, 2020. Comparative analysis methods, a typology, a classification method, a questionnaire, and a method for analysing social factors and events are distinguished among the individual methods that were used in the study.

\section{RESULTS.}

The civil servant's Code of Ethics is a set of general principles of professional official ethics and the basic rules of official conduct that should guide behaviour of federal civil servants regardless of their position. The main goal of the Code is to establish ethical standards and rules of official conduct of civil servants for the worthy performance of their professional activities, as well as to help strengthen the authority of civil servants and the trust of citizens in public authorities.

Since the beginning of the professionalization of public service, civil servants have wanted to be seen as disinterested, responsive, and honest officials. The orderliness of fulfilment of their duties has two components: external, when this orderliness is due to external pressure, and also internal (incentive) component (Filimonova, 2018).

The study allowed us to identify the level of professional ethics of civil servants in the Russian Federation (for example, the Central Office of the State Duma of the Federal Assembly of the Russian Federation)

The answers to the question of how much respondents assess the existence (severity) of the problem on the formation of professional ethics demonstrated by civil servants in the Russian Federation are presented in Figure 1. As we can see, the opinions of civil servants and experts differ, which, in our opinion, can be explained by the overestimated self-esteem of the first. 


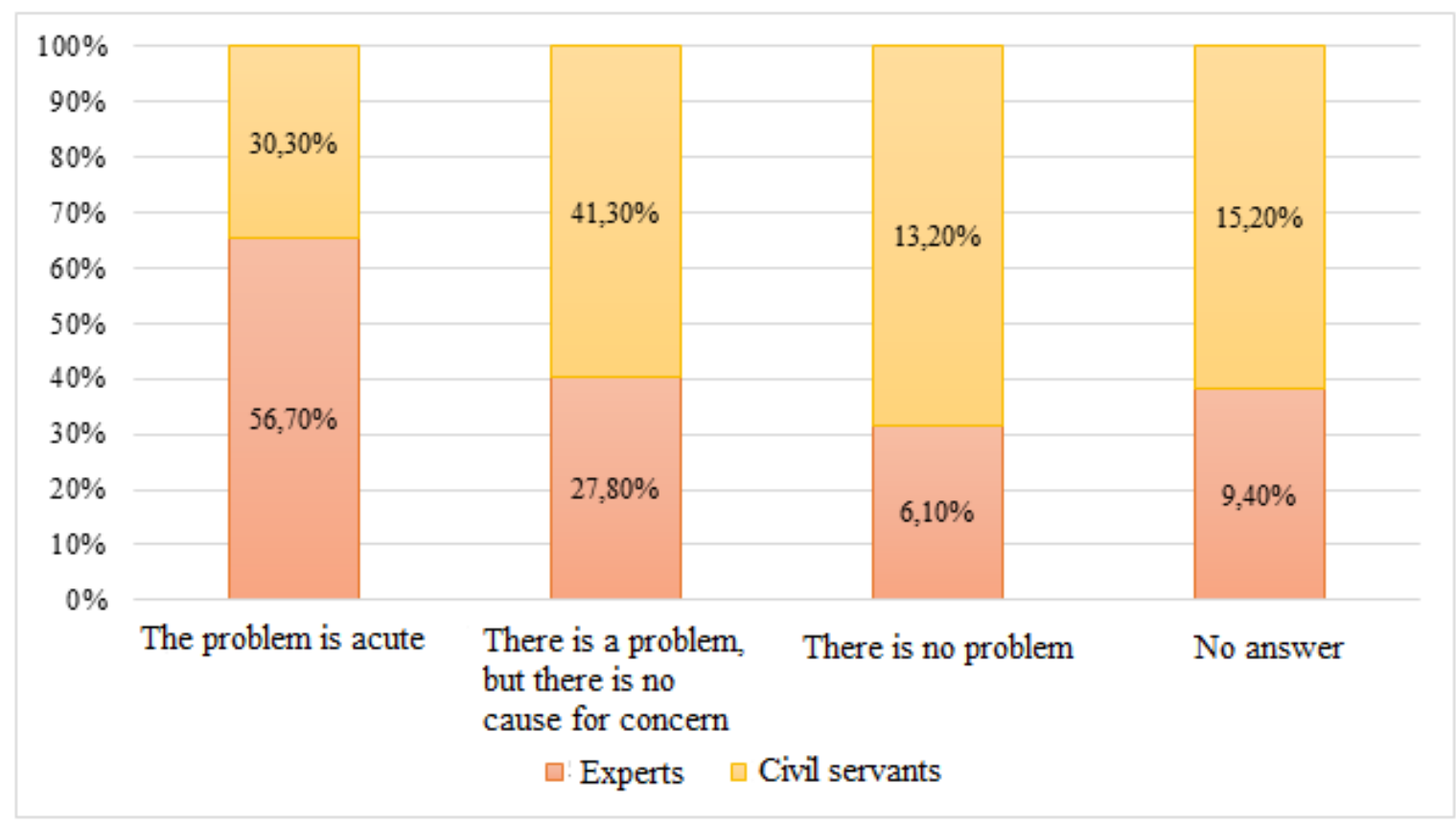

Figure 1. Assessment of the problem severity on the formation of professional ethics demonstrated by civil servants in the Russian Federation, \%.

A detailed analysis of the respondents makes it possible to reveal the main negative qualities that are inherent in modern civil servants (Figure 2). So, for example, $32.4 \%$ of public servants and $47.9 \%$ of experts noted the dishonest performance of their duties, and $34.5 \%$ and $56.7 \%$, respectively, noted the use of their official position for personal selfish purposes. $23.4 \%$ and $33.2 \%$ of respondents noted an irresponsible attitude to their official duties; $31 \%$ and $44 \%$ noted indifference and disrespectful attitude towards people which are consumers of public services. It can be noted that the main negative reviews addressed to public servants are associated not only with the risks of violation of ethical standards by them, but also with official regulations. It is precisely on these points that it is necessary to pay attention, for example, within the framework of a planned addition (change) to the Code of Ethics conducted in the Central Office of the State Duma of the Federal Assembly of the Russian Federation. 


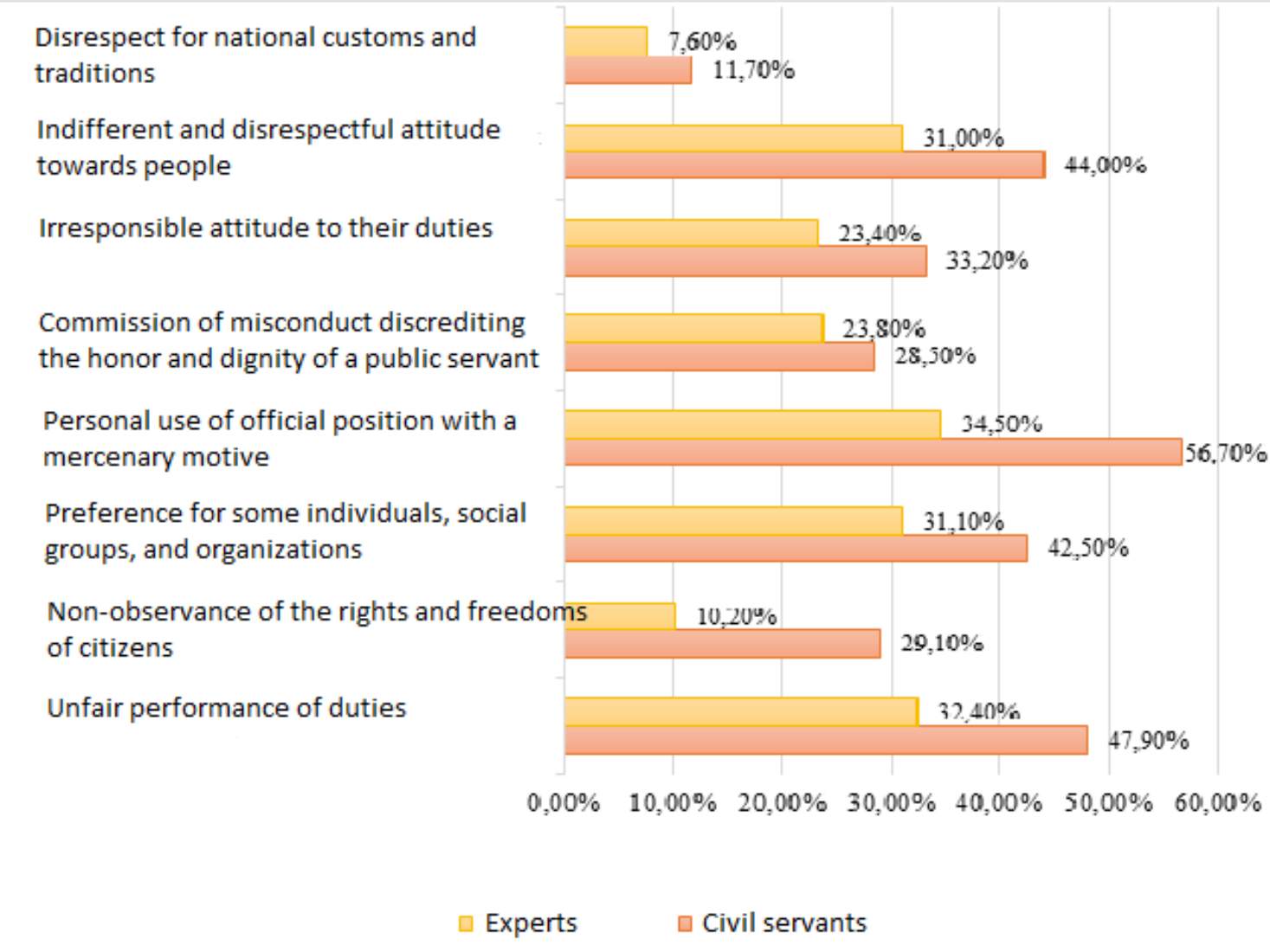

Figure 2. The main negative qualities of civil servants in relation to their professional activities, $\%$.

The question "What is the reason for the manifestation of the negative qualities by civil servants in their professional activities?" had the following answers: firstly, weak legal regulation of the behaviour of public servants $(17.5 \%$ of employees and $28.4 \%$ of experts), and secondly, insufficient development of social norms in the public service system $(19.3 \%$ and $24.6 \%$ ), thirdly, the lack of official demands of higher bodies and (or) managers (18.8\% and $25.4 \%$ ), fourthly, a general decrease in morality in Russian society $(42.5 \%$ and $44.6 \%)$. Also, albeit in a small number of cases, there were problems of lack of official control by society, insufficient civil education of public servants, and insufficient development of social and professional norms in the public service system (Figure 3). 


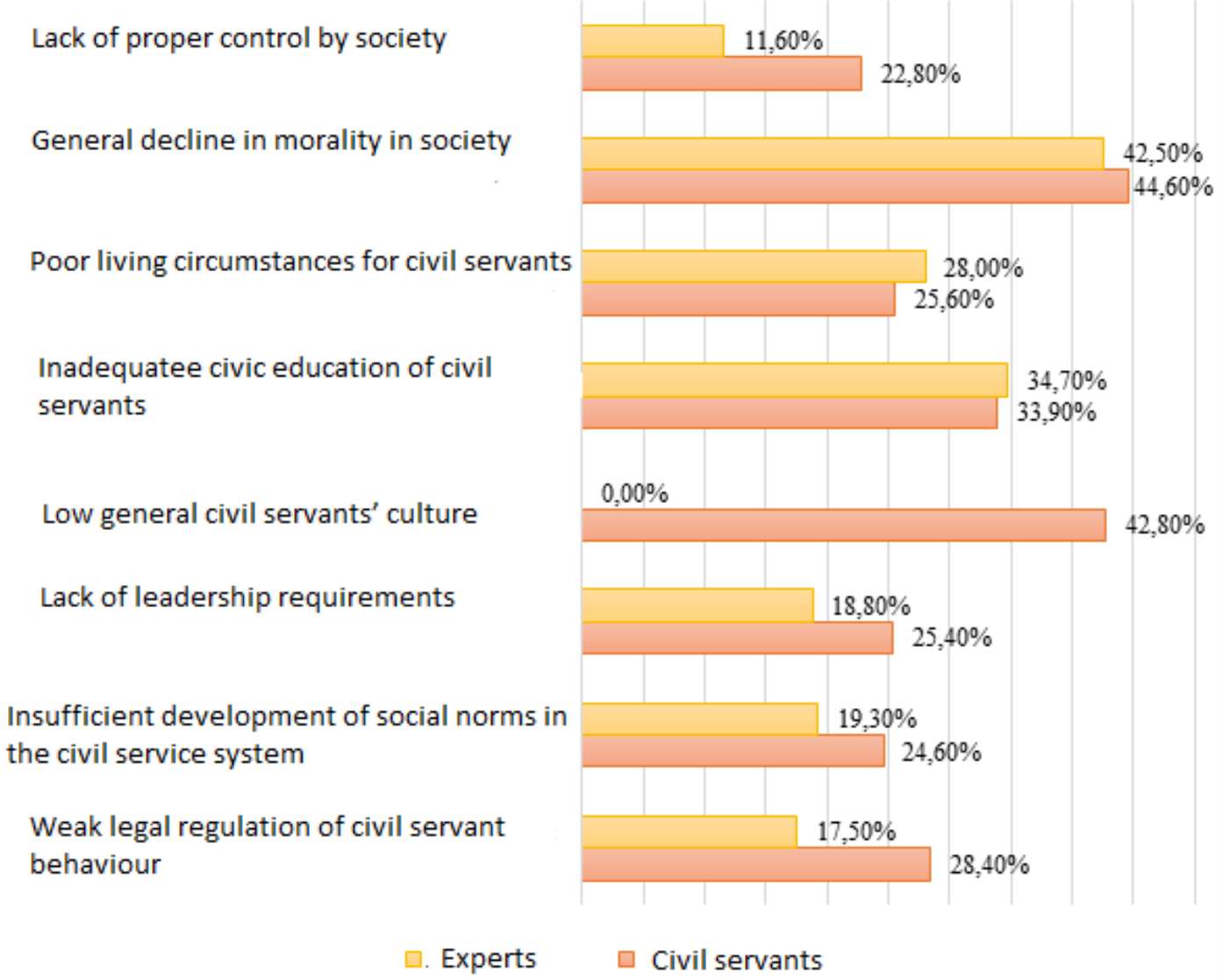

Figure 3. The reasons for the manifestation of the negative qualities by public servants in their professional activities, $\%$.

In general, it should be said that, judging by the answers of the respondents, the public service in Russia is influenced by the processes that take place in society itself, and not in a specific public structure or within the framework of the civil service institution.

In the course of the survey, we asked how well the study participants are aware of the contents of the Model Code of Ethics, as well as codes of ethics of other public structures. Only 38\% of respondents said that they studied these documents. To detail the answers, we asked how long they studied the Model Code of Ethics and the Code of Ethics governing the conduct by the Central Office of the State Duma of the Federal Assembly of the Russian Federation. As a result, we found out that almost $100 \%$ (98.2\%) of the study participants re-read the aforementioned documents for the last time when they entered the service in 
the State Duma of the Russian Federation or the structure preceding it (i.e. they subsequently signed a familiarization act without reading the text Code of Ethics for the Central Office of the State Duma of the Federal Assembly of the Russian Federation). In this regard, we consider it necessary to add to the Code of Ethics for the Central Office of the State Duma of the Federal Assembly of the Russian Federation that he answers. civil servants of this authority should study the text of this document and sign the relevant act repeatedly (after 6 months from the moment of joining the service) and then, for example, once a year. In this regard, the question was asked about the need for repeated and subsequent familiarization with the text of the Code of Ethics for the State Duma of the Federal Assembly of the Russian Federation. Figure 4 shows t

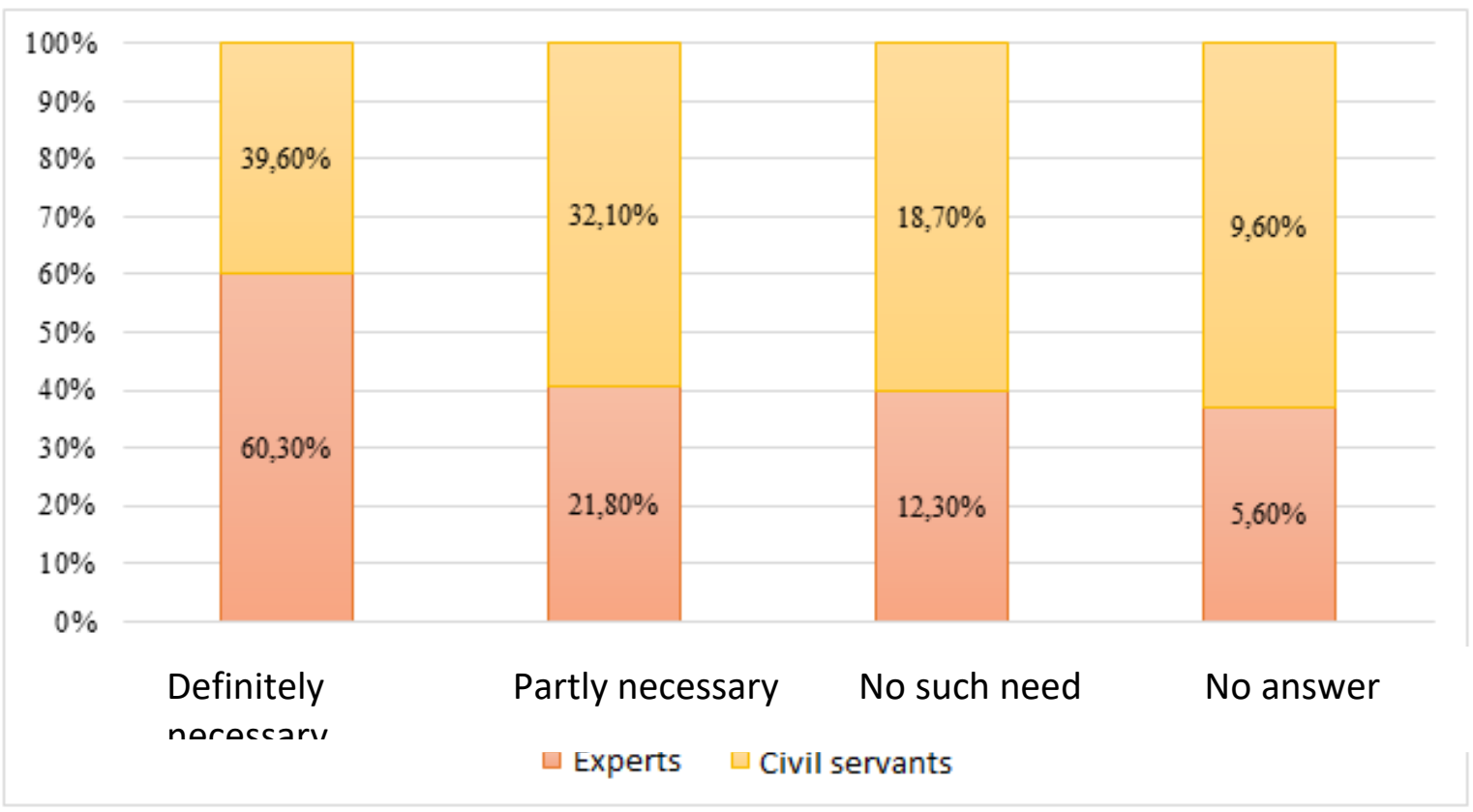

Figure 4. The need for repeated and subsequent familiarization with the text of the Code of Ethics for the State Duma of the Federal Assembly of the Russian Federation, \%.

The diagram shows that the respondents as a whole agree with the need for such an innovation; however, there are much fewer people among them convinced of this than among experts, and there are more people who deny such 
a need. As we have found out, the respondents gave a negative assessment in the connection that, in their opinion, the Code of Ethics for the Central Office of the State Duma of the Federal Assembly of the Russian Federation is "too typical" and requires the integration of "details" (the quote from answers). The answers were distributed as follows regarding exactly which norms should be included in the Code of Ethics (Figure 5).

Both experts and civil servants highlight predominantly the norms that could be consolidated in the Code of Ethics; they are directly involved in the regulation of their official conduct and, first of all, in the processes of interaction with the labour collectives and, oddly enough, the population as consumers of public services. It is worth recalling that the State Duma of the Russian Federation is a social institution, and it accepts appeals from citizens. More than 15 thousand citizens' appeals are processed monthly. In January 2020 alone, the total volume of appeals amounted to 10,197, of which 2.4 thousand were sent to structural units of the Central Office of the State Duma of the Federal Assembly of the Russian Federation (Statistics of appeals to the State Duma, 2020). 


\section{01 - $\mathrm{N}^{\mathrm{o}} 01$ - Ano 2020 - Special Edition}

Requirements for the behavior of public servants on the Internet Recommendations regarding the appearance of civil servants

Balancing the moral qualities of civil servants

Professional self-development of civil servants

Civil servant behavior outside their workplaces

Attitude of civil servants to their professional activities

Interaction with third parties (population)

"Leader - subordinate" relationship

Experts
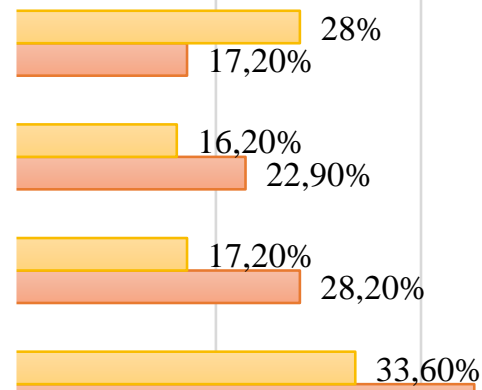

$45,20 \%$

$25,20 \%$ $24,30 \%$

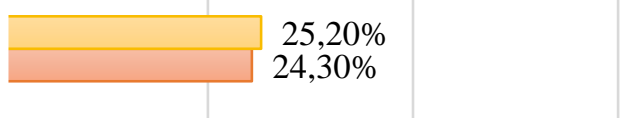

$48,70 \%$ $53,10 \%$

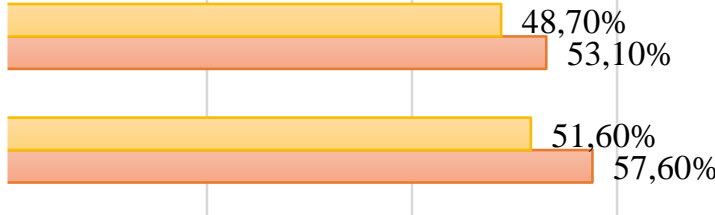

$57,60 \%$

$\square$ Госслужащие $\square$ Эксперты

Figure 5. Norms required for inclusion into the text of the Code of Ethics for the State Duma of the Federal Assembly of the Russian Federation, $\%$.

Among other things, it is interesting to present the results of answers to the last question: what status should ideally have the Code of Ethics of this public structure in general, and the Code of Ethics for the Central Office of the State Duma of the Federal Assembly of the Russian Federation, in particular. The results of the answers are presented in Figure 6. As can be seen from the diagram, most of the answers are focused on the characterization of the document as binding, as $30 \%$ of civil servants and $40 \%$ of experts answered. 


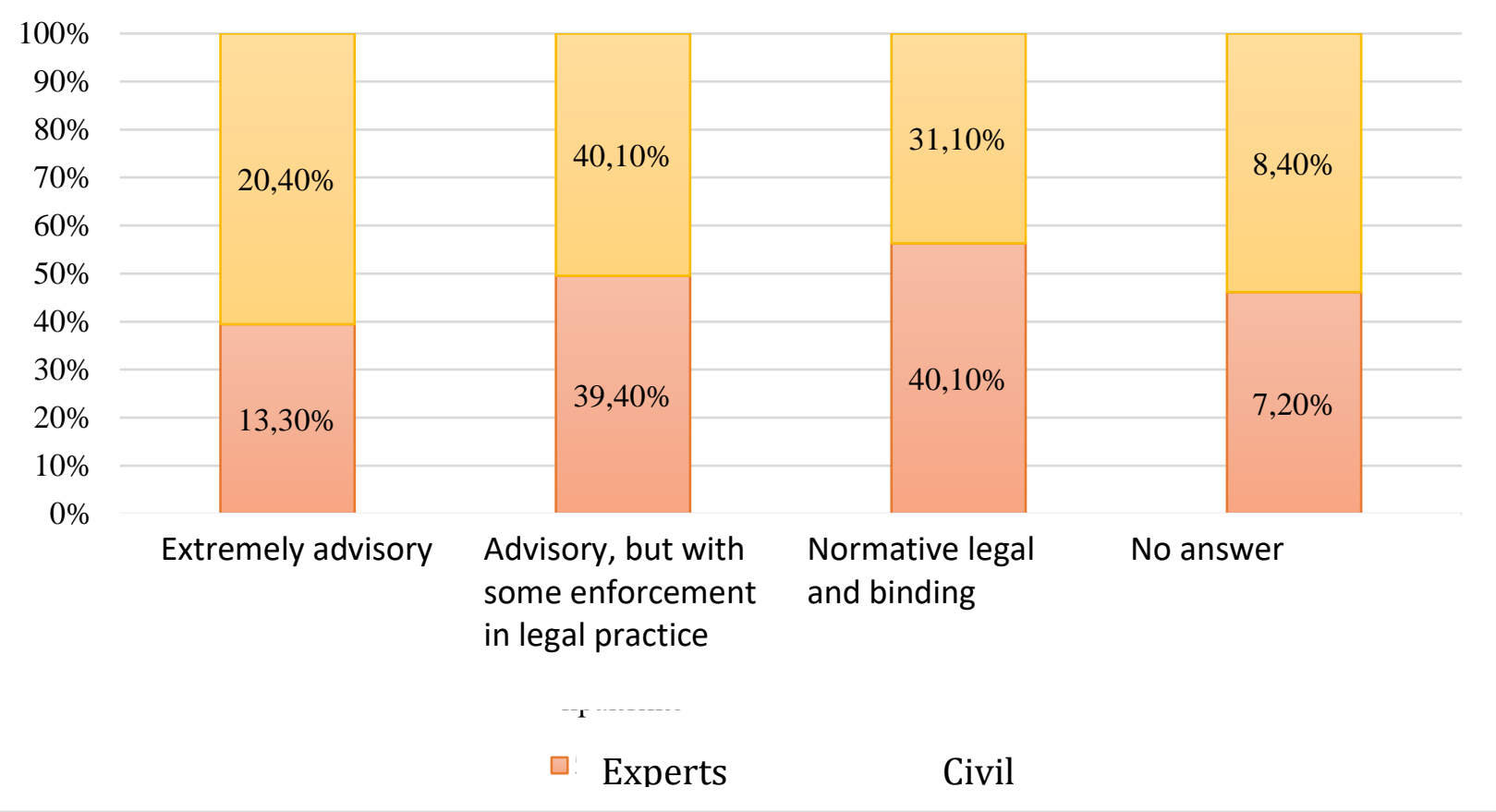

Figure 6. Attitude of respondents to the status that the Code of Ethics should have in the public structure, including in the Central Office of the State Duma of the Federal Assembly of the Russian Federation, \%.

Indeed, only the mandatory implementation of certain provisions and the requirements for the Code of Ethics will minimize the manifestation of the negative qualities of employees of the public structure, and also balance their actions as members of the organization and employees performing the social order.

So, the study allows us to understand the vector of changes and additions that the codes of ethics of federal state bodies need, which for the most part copy the text of the Model Code of Ethics.

\section{DISCUSSION}

Existing programs and technologies for the professional development of civil servants are poorly focused on job competencies and improving the efficiency and effectiveness of professional activities (Merkulov, 2017). In this regard, one should pay attention to the fact that employees of the Civil Service Department and Personnel must ensure that civil servants take special courses (listening to seminars, participating in trainings) on issues of professional ethics. This will make it possible to focus the attention of the State Duma of the 
Russian Federation on this issue (Urzha and etc, 2018). We believe that attending such events will draw the attention of civil servants not only to the ethical problem as a whole, but also to optimize the organizational culture of the staff employed in the State Duma of the Federal Assembly of the Russian Federation, which, as we know, directly positively affects such categories as "competence" and "professionalism", which form the basis for the institute of professional ethics.

Next, we proceed directly to improving the structure of the Code of Ethics for the Central Office of the State Duma of the Federal Assembly of the Russian Federation. This document consists of three units. The first unit is the General Provisions, which includes eight subparagraphs. Clause 1.3 provides information on that a citizen of the Russian Federation who enters the federal public service in the Central Office of the State Duma of the Federal Assembly of the Russian Federation is obliged to familiarize himself or herself with the provisions of the Code and comply with them in the course of all official activities. This paragraph is proposed to be supplemented with the following content: "Each public servant of the Central Office of the State Duma of the Federal Assembly of the Russian Federation is obliged to re-read the provisions of the Code after 6 months from the moment of joining the service and then at least once a year".

The second unit is called "Basic principles and rules of official conduct of civil servants." It consists of fifteen subparagraphs. From our point of view, it is necessary to supplement paragraph 2.2 "Recognizing their responsibility to the state, society and citizens, civil servants are called upon ...:

- To form and develop effective mechanisms for prompt response to appeals of citizens, public associations and the business community of the Russian Federation on the substance of the issues raised in the appeals;

- To improve the forms, methods and ways of working with the media, social networks and forums in the information and telecommunications network "Internet";

- To improve constantly their skills; to strive to improve the quality of their work;

- To promote the formation of the authority of the State Duma of the Federal Assembly of the Russian 
Federation, to increase the reputation of the civil service.

We consider it appropriate to supplement with the term "expenses" the clause 2.7 in the same section, which deals with the obligation of public servants to provide information on income. This will contribute to greater transparency of the remuneration mechanism for employees of the Central Office of the State Duma of the Federal Assembly of the Russian Federation and reduce the corruption factor in this public structure.

Further, it is proposed to expand Section 2.12, which states that in relation to colleagues, a public servant should be "an example of professionalism for them, an impeccable reputation, and contribute to the formation of a moral and psychological climate favourable for effective work in the Central Office of the State Duma Administration and its structural divisions." In the Model Code of Ethics, there are only three specific points (they are presented in clause 2.3 of the Code of Ethics for the Central Office of the State Duma of the Federal Assembly of the Russian Federation), but we propose to supplement clause 2.12 with new clauses:
- Regulate relationships within the staff based on the principles and norms of professional ethics;

- Treat subordinate civil servants as individuals, recognizing their right to have their own professional judgments;

- Show high exactingness, integrity in combination with respect for personal dignity: not to allow arrogance, dismissive tone, rudeness, incorrect and offensive remarks, unfounded claims and accusations;

- Not discriminate others on the basis of sex, racial, national, religious, age or political grounds;

- Avoid demonstrating religious and political symbolism in the event that this may offend the feelings of other public servants and citizens of the Russian Federation;

- Establish a fair, uniform workload of subordinates; avoid discrimination by providing individual public servants with undeserved benefits and privileges;

- Provide comprehensive support and assistance to young professionals in acquiring professional skills;

- Ensure the confidentiality of information that has become known to 
them in connection with the performance of official duties affecting the private life, honour and dignity of a citizen;

- Not to allow patronage, career advancement, provision of benefits on the grounds of kinship, fraternity, personal loyalty, as well as with the aim of obtaining selfish gain;

- Support and protect subordinates in the event of their unjustified accusation of corruption or violation of ethical standards.

Paragraph 2.13 can be formulated as follows: "A civil servant endowed with organizational and administrative powers in relation to other civil servants, is called upon to prevent: a) shifting his or her responsibility to subordinates; b) manifestations of formalism, rudeness and arrogance; c) promoting an atmosphere of mutual responsibility, creating conditions for whispering and denunciations in their team; d) manifestations of protectionism, nepotism, favouritism, as well as abuse of authority."

The third unit "Recommended Ethical Rules for the Official Conduct of Civil Servants" contains only four points. We consider it necessary to draw the attention of civil servants to the fact that, in the context of the second part of
Section 3.3 from the Code of Ethics for the Central Office of the State Duma of the Federal Assembly of the Russian Federation, it is important to maintain a favourable moral and psychological climate in the team. It is expressed in a positive emotional and moral state, high morale of the employees of the State Duma, their attitude to moral values and the degree of motivational readiness to perform official tasks. This thesis can be attributed to a separate paragraph (i.e. 3.4) of the following content: "Civil servants should be polite, friendly, correct, attentive and tolerant in dealing with citizens and colleagues in their civil service, as well as contribute to maintaining a healthy moral and psychological climate in the team. The favourable moral and psychological climate in the staff is characterized by: a) understanding by employees the goals of the activities of the state body, local government and their structural unit; b) the ability and willingness to work together to achieve the objectives; the degree of comfort of public service, the social well-being of the team; c) the level of development of relationships based on honesty and integrity in combination with mutual assistance and respect; d) positive service traditions, uniting the 
team. Criticism of deficiencies in the work should be expressed in the presence of the person in respect of whom it exists; it should be expressed in the correct form (without humiliating the honour and dignity of the person), be objective, balanced, principled and accepted with understanding by the state (municipal) employee to whom it was addressed."

As a recommendation, we propose to supplement the section with the following paragraphs " 3.4 . In their official activities, civil servants are obliged...:

- Be faithful to civic and official duty;

- Fiercely combat any violation of the law;

- Timely take effective measures to protect the rights and freedoms of person and citizen protected by law, as well as the interests of society and the state, to seek elimination of violations of the law and restore violated rights;

- Not to allow bureaucracy, formalism, arrogance, disrespectful attitude to legitimate requests and requirements of citizens, to show correctness and attentiveness in communication with citizens;
- Not to allow their political and religious convictions and personal relations to influence their decisionmaking related to the performance of official duties;

- Maintain independence, show tact and respect, exactingness and integrity in relations with representatives of state authorities, local authorities, and public associations, commercial and non-profit organizations;

- Prevent legal or physical persons from being requested for information that is not provided by law concerning these persons;

- Control their behaviour, feelings and emotions, not allowing personal likes or dislikes, hostility, unkind mood or friendly feelings to influence decisions; be able to predict the consequences of their actions and actions;

- Refrain from personal relations, which obviously can damage their reputation and authority, affect the honour and dignity of state public servants or call into question their objectivity and independence;

- Refrain from criticizing officials and employees in the presence of individuals if critical statements are 
not related to the performance of official duties;

- Exclude the use of their own official position, including the use (presentation) of an official certificate, for personal interests not related to the performance of official duties

- Proceed in their official activities, as well as outside their official activities, from the moral, cultural, political and other values that have developed in society that form positive expectations regarding the behaviour of public servants;

- Take initiative in solving assigned tasks; willingness to make efforts to obtain the best possible result.

Currently, there is a need to draw the attention of public servants to the problem of Internet communication. In this regard, clause 3.6 may contain the following information: "3.6. When using forums, social networks and other social services on the Internet, civil servants should not defame the honour of the public service in general, and the State Duma in particular. When using their personal accounts on social networks in the information and telecommunication network "Internet", a state (municipal) employee must also refrain from...:
- Any kind of statements and acts of a discriminatory nature on the grounds of sex, age, race, nationality, language, citizenship, social, property or family status, political or religious preferences;

- Rudeness, manifestations of a dismissive tone, arrogance, prejudice, unlawful, undeserved accusations;

- Threats, offensive expressions or remarks and actions that interfere with normal communication or provoke illegal behaviour;

- Commenting on entries in the information and telecommunication network "Internet" on behalf of a state body or local government;

- Placement of illegal information, or information that can cause a wide public resonance;

- Placement of photo-, audio-, video- and other materials containing the approval of the use of alcoholic beverages, narcotic drugs, the commission of unlawful acts, as well as confirming the facts of a person's participation in events of a dubious moral orientation, including those containing information on the support of persons organizing (participating) in such events, that is, materials that can raise doubts about the decency of public 
servants in their moral and ethical qualities and personal integrity.

The changes and additions we propose to the Code of Ethics for the Central Office of the State Duma of the Federal Assembly of the Russian Federation will minimize problems in the mechanisms for the formation of professional ethics manifested by civil servants of the State Duma of the Russian Federation (Evstratova et al., 2020). The significance of the amendments and additions is justified by the possibility of integrating the presented provisions into any of the existing codes, regardless of the degree of identity with the Model Code of Ethics and official conduct of public servants of the Russian Federation.

\section{CONCLUSIONS}

The study conducted made it possible to assess the attitude of civil servants to professional ethics. Based on the results of the survey, the main negative qualities of civil servants in relation to their professional activities were identified: unprincipled performance of their duties, the use of official position for personal selfish purposes, irresponsible attitude to their official duties, indifference and disrespectful attitude towards people consumers of public services, etc. At the same time, the main reasons for such a manifestation of negative qualities, according to public servants, are that there is a weak legal regulation of the behaviour of public servants, the social standards are not well developed in the civil service system; there are no job requirements of higher authorities and (or) managers; there is a general decrease in morality and dignity in society. In addition, there is a fairly low level of awareness among government officials about the content of the Code of Ethics.

All this necessitated the strengthening of measures to modernize the Code of Ethics for civil servants. The proposed changes and additions will minimize problems in the mechanisms for the formation of professional ethics of civil servants in federal authorities.

\section{REFERENCES}

Bota-Avram, Cristina. (2013). Is Ethical Behaviour of Companies Influenced by Governance? International Advances in Economic Research. 19. 10.1007/s11294-013-9427-y.

Evstratova T.A., Medvedeva N.V., Kalinichenko L.A. (2020). Analysis the impact of literature on the formation of 
the Russian Federation state civil servant image in mass media. PROPOSITOS Y REPRESENTACIONES. Vol. 8. № 2. P. 13.

Fattah, Moataz. (2011). Professional Ethics and Public Administration in the United States. International Journal of Public Administration. 34. 65-72. 10.1080/01900692.2010.524088

Fejzullahu, Artan \& Batalli, Mirlinda. (2019). The role of ethics in public administration. SEER. 22. 267-278. 10.5771/1435-2869-2019-2-267.

Ferreira, Fernanda \& Castro, Conceicao \& Lopes, Cristina. (2019). Does corruption in the public sector reduce corporate ethics? - A panel data analysis. AIP Conference Proceedings. 2186. 090004. 10.1063/1.5138000

Giovanola, Benedetta. (2011). Ethics and Public Administration: On the Italian Case and Beyond. International Journal of Public Administration. 34. 5964. 10.1080/01900692.2010.524087.

Hallunovi, MSc \& Osmani, Dr.Sc \& Bashi, Elidiana. (2014). Ethics in Public Administration. ILIRIA International Review. 4. 201. 10.21113/iir.v4i1.61.

Nedelko, Zlatko \& Potocan, Vojko. (2013). Ethics in Public Administration: Evidence from Slovenia. Transylvanian
Review of Administrative Sciences. 9. 88-108.

Radhika, D. (2012). Ethics in Public Administration. Journal of Public Administration and Policy Research. 4. 10.5897/JPAPR11.049.

Sumra, Kalsoom. (2019). Public Service Ethics in Public Administration: An Empirical Investigation.

Urzha O., Kataeva V., Evstratova T. (2018). Sociology of governance as a methodology for developing scenarios for simulation case studies in the governance training system // International Scientific Conference on Economic and Social Development. P. 627-636.

Vasiljevic, Dragan. (2016). Contribution to the problem of ethics of public administration personnel. Nauka, bezbednost, policija. 21. 111-122. 10.5937/nbp1602111V.

Atamanchuk G.V. (2013). Problems of increasing the efficiency of administrative regulation of public administration in the Russian Federation. Bulletin of Moscow University. Series 26. State Audit, p. 34-47

The Code of Ethics and Official Conduct of Federal State Civil Servants of the Central Office of the State Duma of the Federal Assembly of the Russian 
Federation approved by order of the Head of the Central Office of the State Duma of the Federal Assembly of the Russian Federation dated March 14, 2011 No. 2-40

Merkulov P.A. (2017) Professional development as an element of the state policy intended on increasing the efficiency of the state civil service // Bulletin of the Expert Council. No. 1 (8).

\section{S.107-111}

Methodological recommendations on the issues of reporting information on income, expenses, on property and liabilities of a property nature and filling out the corresponding enquiry form in 2020 (for the 2019 reporting year). Letter of the Ministry of Labour and Social Protection of the Russian Federation dated December 27, 2019 N 18-2 / 10 / B-11200). // Portal "GARANT". ULR: https://www.garant.ru/products/ipo/prim e/doc/73274589/ (date of access: 06.03.2020)

Obolonsky A.V. (2011) The crisis of the bureaucratic state: Civil service reforms: international experience and Russian realities. Moscow.

Ovsyanko D.M. (2008). State service of the Russian Federation. Moscow: Lawyer. P. 176-180.
Omelchenko N.A. (2005) The political culture of society and the reform of state power and management // Marketing. 2005. No. 6 (85).

Regulation on the Central Office of the State Duma of the Federal Assembly of the Russian Federation (edition of 03.13.1998) approved by order of the Chairman of the State Duma of the Federal Assembly of the Russian Federation dd. 23.03.1996 N 112 / 1p-1 // ATP "Consultant Plus"

Statistics of appeals to the State Duma (2020). Reception of the State Duma of the Russian Federation SAS "Zakonotvorchestvo". ULR: https: //priemnaya.duma.gov.ru/ru/stat_page/a 1l/ (accessed: 01.03.2020)

Decree of the President of the Russian Federation dd. July 1, 2010 N 821 (as amended on September 19, 2017) “On Commissions for Compliance with the Requirements for the Official Conduct of Federal Public Servants and Settlement of Conflicts of Interest" (together with the "Regulation on Commissions for Compliance with the Requirements for Official Conduct of Federal civil servants and the settlement of conflicts of interest ") // Collection of the legislation of the Russian Federation, $\mathrm{N}$ 27, Art. 3446. 
Decree of the President of the Russian

Federation dd. 08.08.2002 N 885 (edition of 16.07.2009) "On the approval of the general principles of official conduct of public servants" // Collection of legislation of the Russian Federation, N 33, Article 3196

Federal Law of July 27, 2004 N 79-FZ (edition of December 16, 2019) "On the State Civil Service of the Russian Federation" // Collected Legislation of the Russian Federation, No. 31, Art. 3215.

Filimonova O.V. (2018) Professional ethics in the mechanism of public administration. // Proceedings of the Academy of Management under the Ministry of Internal Affairs of Russia. No. 2 (46). P.67-70

Frolov O.V. (2017). The values of the professional activities of public servants // Values and meanings. No. 1. P. 136145.

Shuvalova N.N. (2013). Management of moral relations in the public service system: orientation to success. Law and Management. XXI Century. No. 2 (27). P.41-48.

The Code of Ethics for civil servants of the Russian Federation (2010). // URL: http: //www.rb.ru/inform/98977.html (access date: 10/02/2020) 